\title{
Костянтин Підгорний
}

аспірант кафедри педагогіки і психології управління соціальними системами ім. академіка

I. Зязюна, Національний технічний університет "Харківський політехнічний інститут”;

Харків, Україна

E-mail:podgornyi84@gmail.com

\section{СУТНІСТЬ ЛІЕРСЬКОЇ ПОЗИЦІЇ МАЙБУТНІХ ФАХІВЦІВ ПУБЛІЧНОГО УПРАВЛІННЯ ТА АДМІНІСТРУВАННЯ}

Анотаиія: у статті проаналізовано зміст таких понять, як “позиція”, “лідер”, “лідерство”, “лідерська позиція"; на підставі аналізу наукової літератури доведено, що більшість робіт науковців присвячена дослідженню лідерства як явищої соціокультурної дійсності, виробленню підходів щодо формування та розвитку лідерських якостей. Надано визначення сутності лідерської позиції майбутніх фахівців публічного управління та адміністрування як синергії. Надано авторське трактування сутності лідерської позиції майбутніх фахівців публічного управління та адміністрування як синергію їхніх особистісних, професійних, громадянських якостей, дій i вчинків, спрямованих на реалізацію його основної місії - готовності забезпечити конструктивну взаємодію публічної влади, освіти, науки, бізнесу і громадського суспільства.

Ключові слова: позиція, лідер, лідерство, лідерська позиція, майбутні фахівці публічного управління та адміністрування, заклад вищої освіти.

\section{Kostiantyn Pidgornyi}

graduate student of the department of pedagogy and psychology of management of social systems academician I. Zyazyun, National Technical University "Kharkiv Polytechnic Institute";

Kharkiv, Ukraine

E-mail: podgornyi84@gmail.com

\section{THE ESSENCE OF THE LEADERSHIP POSITION OF FUTURE PUBLIC MANAGEMENT AND ADMINISTRATION SPECIALISTS}

Abstract: the essence of such concepts as "position", "leader", "leadership", "leadership position" is revealed in the article, based on the analysis of the scientific literature it is proved that most of the works of scientists are devoted to the study of leadership as such, to the working out the approaches to the formation and development of leadership qualities, the author's interpretation of the essence of the leadership position of future specialists in public management and administration is given, which is seen as a synergy of their personal, professional, civic qualities, actions and deeds aimed at implementing their main mission, that is readiness to ensure constructive interaction of public authorities, education, science, business and civil society.

Key words: position, leader, leadership, leadership position, future specialists in public management and administration, institution of higher education.

\section{Константин Подгорный}

\section{СУЩНОСТЬ ЛИДЕРСКОЙ ПОЗИЦИИ БУДУЩИХ СПЕЦИАЛИСТОВ ПУБЛИЧНОГО УПРАВЛЕНИЯ И АДМИНИСТРИРОВАНИЯ}

Аннотащия: в статье проанализировано содержание таких понятий, как “позиция”, “лидер”, “лидерство”, “лидерская позиция"; На основании анализа научной литературы доказано, что большинство работ ученых посвящено исследованию лидерства как явления социокультурной

(C) Костянтин Підгорний, 2021 
действительности, выработке подходов к формированию и развитию лидерских качеств. Дано определение сущности лидерской позиции будущих специалистов публичного управления и администрирования как синергии. Дана авторская трактовка сущности лидерской позиции будущих специалистов публичного управления и администрирования как синергия их личностных, профессиональных, гражданских качеств, действий и поступков, направленных на реализацию его основной миссии - готовности обеспечить конструктивное взаимодействие публичной власти, образования, науки, бизнеса и общественного общества.

Ключевые слова: позиция, лидер, лидерство, лидерская позиция, будущие специалисты публичного управления и администрирования, заведение высшего образования.

\section{Kostiantyn Pidgornyi}

An extended abstract of the paper on the subject of:

\section{"The essence of the leadership position of future public management and administration specialists"}

Problem setting. A radical change in views on the state's mission to ensure human and civil rights and freedoms puts new demands on the professional competence of public administration, which requires training programs focused on the creative experience of European and world universities, on the training of future specialists in public management and administration, in particular, on the formation of their leadership position.

Recent research and publications analysis.The works of domestic and foreign scientists such as F. Zimbardo, O. Kuchabsky, S.House, D. Dzvinchuk, S. Dombrovskaya, L.Hren, V. Kuhn, V. Kremen, V. Lugovoi, V. Moroz, O. Parkhomenko-Kutsevil and others are devoted to the development of education at the state level. Leadership in education is patronized by L. Hren, T. Hura, S. Kalashnikov, I. Kostyrya, S. Nestulya, O. Romanovsky, O. Ponomarev, S. Reznik, V. Strelnikov and other researchers. The dissertation researches of B. Goloveshko, I. Kostyra, O. Polisaev and other authors are worth of attention.

Highlighting the previously unresolved parts of the general problem. Based on the analysis of scientific literature and modern approaches to the training of public management professionals, the question of the essence of the leadership position of future specialists in public management and administration and its formation in higher education remains unresolved.

Paper objective. On the basis of the analysis of the scientific literature to find out the peculiarities of the essence of the leadership position of future specialists in public management and administration.

Paper main body. To facilitate the transition to a horizontal system of public coordin- ation of making and implementing mana-gement decisions with the participation of all stakeholders at national, regional and local levels [14], which, in turn, requires quality training of public management and administration in higher education. Only those specialists of public management and administration who have a leadership position are able to act in the interests of the individual, community, and state.

Scholars define position as a component of personality structure that dialectically combines motivational, emotional, intellectual, behavioral and activity aspects as a characteristic that allows us to consider an individual as a subject of social relations. In the theory of public management, the term "leadership" is seen as a managerial relationship between the leader and subordinates, based on an effective combination of different sources of power and aimed at encouraging people to work to achieve set goals. Leader is a person in any group who uses a recognized authority, has an influence that manifests itself as a governing action [11, p. 14].

The works of $V$. Bondarenko, T. Hura, B. Goloveshko, O. Romanovsky I. Kostyria, $S$. Reznik, are devoted to the formation of a leadership position of future engineers. "Leadership is a process of influencing people, which is generated by the system of informal relations, and management involves a clearly structured formal relationship, through which it is implemented" [11, p. 13]. We consider the essence of the leadership position of the future specialist in public management as a synergy of their personal, professional, civic qualities, actions and deeds aimed at implementing the main mission, that is readiness to ensure constructive interaction of public authorities, education, science, business and civil society. 
Conclusions of the research. According to our research, we give the author's definition of the essence the leadership position of future specialists in public management and administration is defined as a synergy of their personal, professional, civic qualities, actions and deeds aimed at achieving the main mission, that is readiness to ensure constructive interaction of public authorities, education, science, business and civil society, it is proved that the comprehensive

Постановка проблеми в загальному вигляді та її зв'язок із важливими науковими чи практичними завданнями. Орієнтація Стратегії сталого розвитку України до 2030 року спрямована на вектори розвитку, відповідальності, гордості. Суттєві зміни нашої країні, що пов'язані з курсом на євроінтеграцію, надають “можливість побудувати нову Україну на принципах сталого розвитку, верховенства права, захисту прав людини, демократії, солідарності, належного врядування" [14]. Докорінна зміна поглядів щодо місії держави стосовно забезпечення прав $\mathrm{i}$ свобод людини, громадянина висувають нові вимоги до професійної компетенції державноуправлінських кадрів [1, с. 8], що вимагає орієнтації навчальних програм на креативний досвід європейських і світових 3ВО, зокрема щодо навчання майбутніх фахівців публічного управління та адміністрування, щодо формування їхньої лідерської позиції.

Аналіз останніх досліджень і публікацій, у яких започатковано розв'язання цієї проблеми і на які спирається автор. Розвитку освіти на рівні держави присвячено роботи вітчизняних та зарубіжних науковців, зокрема Л. Грень, Д. Дзвінчука, С. Домбровської, Ф. Зімбардо, В. Кременя, В. Кучабського, В. Кун, В. Мороза, О. Пархоменко-Куцевіл, В. Лугового, О. Хаус та інші. У роботах цих дослідників розглядається розвиток системи освіти як невід'ємна, важлива частина державної політики. Наводиться аналіз системи освіти, сформовані наукові рекомендації щодо iii ефективного розвитку. Лідерством в освіті опікуються С. Калашникова, I. Костиря, Т. Гура, С. Нестуля, О. Пономарьов, С. Резнік, В. Стрельніков та інші вчені. Ці дослідники у наукових пошуках спираються на фундаментальні дослідження зарубіжних вчених. Вони розробили теоретико-методологічні та практичні підходи до формування майбутньо- development of the personality of future specialists in public administration will be able to provide quality professional education aimed at forming a leadership position of future specialists in public management and administration.

Promising areas of further research are the analysis of European experience in forming a leadership position of future specialists in public management and administration.

го фахівця-лідера. У розрізі сучасних українських реалій феномен лідерства розглядає О. Пономарьов. Окремо варто сказати про фундаментальні роботи відомого вітчизняного вченого О. Романовського. Серед них слід виділити дослідження присвячені феномену харизматичного лідерства. Саме аналіз феномену харизматичного лідерства особливо важливий у межах нашого дослідження.

На увагу заслуговують дисертаційні дослідження Б. Головешка ("Педагогічні умови формування лідерських якостей у майбутніх фахівців з адміністративного менеджменту у вищих навчальних закладах", 2017, де теоретично обгрунтовано, розроблено та експериментально перевірено педагогічні умови формування лідерських якостей у майбутніх фахівців із адміністративного менеджменту у 3ВО) [3], I. Костирі (“Формування лідерської позиції майбутніх інженерів у вищих технічних навчальних закладах", 2018; теоретично обгрунтовано, розроблено та експериментально перевірено педагогічні умови формування лідерської позиції майбутніх інженерів у закладах вищої освіти технічного профілю) [5] та інших дослідників.

Виділення не вирішених раніше частин загальної проблеми, котрим присвячується дана стаття. На підставі проведеного аналізу наукової літератури та сучасних підходів до підготовки професіоналів у сфері публічного управління невирішеним залишається питання сутності лідерської позиції майбутніх фахівців публічного управління та адміністрування та iï формування у закладі вищої освіти.

Формулювання цілей статті (постановка завдання). На підставі аналізу наукової літератури визначити сутність лідерської позиції майбутніх фахівців у сфері публічного управління та адміністрування. 
Виклад основного матеріалу дослідження 3 повним обгрунтуванням отриманих наукових результатів. Одним із керівних принципів стратегії сталого розвитку України до 2030 року $\epsilon$ належне врядування, яке повинно “забезпечити результативність, ефективність, відкритість та інклюзивність управлінського процесу, підзвітність та відповідальність суб' єктів управління, сприяти переходу до горизонтальної системи суспільної координації прийняття та реалізації управлінських рішень за участі всіх зацікавлених сторін на національному, регіональному та місцевому рівнях" [14], що, вимагатиме якісної підготовки фахівців у сфері публічного управління та адміністрування у закладах вищої освіти. Сучасні наукові дослідження вказують на "принципово нові підходи до підготовки цієї категорії фахівців детерміновані необхідністю реалізації в державі системних соціально-економічних перетворень одночасно із захистом територіальної цілісності та збереження суверенітету України" [1, с. 12]. Діяти в інтересах людини, громади, держави здатні тільки ті фахівці у сфері публічного управління та адміністрування, які мають лідерську позицію.

У контексті нашого дослідження вважаємо за доцільне визначитися з такими поняттями, як: “позиція”, “лідерство”, “лідер”.

Словник української мови визначає позицію як “точку зору, ставлення до чого-небудь, що визначає характер поведінки, дії” [12].

Науковці визначають позицію як компонент структури особистості, що діалектично поєднує мотиваційні, емоційні, інтелектуальні, поведінкові та діяльнісні аспекти (В. Войтко, О. Киричук, О. Кононко, В. Панок, О.Петровський); як характеристику, що дозволяє розглядати особистість як суб'єкт соціальних відносин (Н. Дивитовська, Б. Паригін) [16, с. 6 ].

3 поняттям “позиція” тісно пов' язано поняття “громадянська позиція”, що, на думку дослідників, є “інтегративною якістю, утвореною сукупністю мотиваційного, когнітивного, вольового, емоційного й поведінкового компонентів, що визначає ставлення людини до обов'язків перед суспільством і державою як їхне внутрішне прийняття та готовність до неухильного виконання" [2, с. 110].

Поняття “громадянська позиція", на наше переконання, пов'язано із поняттям “лідерство”. На думку Б. Головешка, “феномен лідерства необхідно розглядати в контексті існування та діяльності певної групи людей. У цих випадках лідера характеризує безпосе-редня участь у досягненні поставленої мети" [3].

Закордонні дослідники тлумачать лідерство, беручи за основу різні концептуальні ідеї та підходи. Наприклад Р. Стогділл у своєму "Довіднику 3 лідерства" сконцентрував уявлення науковців про лідерство у таких, на його думку, головних ідеях: лідерство як центр групових інтересів, як характеристика особистості, як мистецтво досягнення згоди або підпорядкування, як дія й поведінка, як інструмент досягнення мети або бажаного результату, як взаємодія, як уміння переконувати, як здійснення впливу, як владні відносини, як результат рольової диференціації, як ініціація або конструювання структури групи [17] Р. Кричевський додав таку характеристику: лідерство як процес соціальної перцепції [6], а дослідниця О. Кудряшова - як бачення перспективи та як дотримання особливих цінностей [7].

На думку авторського колективу на чолі 3 О. Романовським, “лідерство - це процес впливу на людей, який породжений самою системою неформальних відносин, а управління передбачає наявність чітко структурованих формальних відносин, завдяки яким воно реалізується" [11, с. 13]. Під лідерством звичайно розуміють один із процесів організації малої соціальної групи та управління нею, який сприяє досягненню групової мети в оптимальний термін і $з$ оптимальним ефектом, детермінований панівними в суспільстві соціальними відносинами [4].

У теорії державного управління термін “лідерство" розглядається як управлінські взаємовідносини між керівником і підлеглими, засновані на ефективному поєднанні різних джерел влади і спрямовані на спонукання людей працювати на досягнення поставлених цілей [13].

Автори багатьох наукових робіт із лідерства (С. Калашнікова, О. Романовський, Т. Гура) досліджують лідерство через професійну підготовку лідерів. Наукові розвідки В. Біленко, М. Морарь, А. Пахарєва, Н. Трач присвячені дослідженню політичного лідерства, дослідженню організаційного лідерства присвячено роботи Л. Карамушки, О. Філь. Погоджуємося $з$ думкою дослідниці І. Костирі, 
що “абсолютна більшість робіт присвячена дослідженню лідерства як такого, виробленню підходів щодо формування та розвитку лідерських якостей” [5, с. 6].

Лідер (від англ. leader - ведучий, перший, той, хто йде попереду) - особа у будьякій групі, яка користується визнаним авторитетом, має вплив, що виявляється як керуюча дія [11, с.13].

Формуванню лідерської позиції майбутніх інженерів присвячено роботи Т. Гури, В. Бондаренко, Б. Головешка, С. Резнік, О. Романовського, А. Черкашина, які у своїх наукових напрацюваннях розробляють теоретичні засади, практичні рекомендації щодо формування лідерської позиції майбутніх інженерів у закладах вищої технічної освіти під час аудиторної та позааудиторної діяльності [15]; обгрунтовують педагогічні умови формування лідерських якостей майбутніх фахівців із адміністративного менеджменту та аналізують особливості розвитку лідерських якостей у майбутніх психологів [8]; висвітлюють питання особливостей створення іміджу лідера - професіонала і надають рекомендації щодо їхнього застосування у практичній діяльності, у формуванні позитивного соціально-психологічного клімату в колективі [9]. Досліджуючи поняття “лідерська позиція”, наводимо визначення цього феномена науковцями. Так, за визначенням I. Костирі, “лідерська позиція майбутніх інженерів виступає як особистісна характеристика, що включає в себе усвідомлення майбутнім інженером готовності до виконання ролі лідера та здатності до організаційного впливу на виробничий колектив; лідерська позиція грунтується на лідерському потенціалі майбутнього інженера та формується під час засвоєння лідерської ролі в різних життєвих ситуаціях, включаючи умови професійної інженерної сфери" [5, с. 4]. О. Хмизова характеризує “лідерську позицію” школярів як комплексне, відносно стійке, динамічне особистісне утворення, що характеризується певною системою ставлень особистості до людей та до самої себе у складних соціальних відносинах; зовнішньо вона виявляється у лідерській поведінці та діяльності; внутрішньо лідерська позиція зумовлюється системою установок, цілей і цінностей та відображає характер іï потреб, мотивів і переконань [12, с. 4].

Грищенко I. пояснює сутність лідерської позиції так: “Лідер здійснює вчинки (“акти лідерства"), структура яких характеризується елементами, що взаємодіють між собою i змінюються, певними особистісними рисами лідера, його здібностями, можливостями для реалізації цілей інших людей у процесі ситуаційної взаємодії. Таке домінування існує всередині групи, де лідер займає певну позицію та виконує роль задля досягнення цілей групи, колективу... Лідер, для збереження своєї позиції, повинен бути чутливим до потреб i запитів групи" [4, с. 119].

Лідерська позиція майбутніх фахівців у сфері публічного управління та адміністрування - це особиста характеристика студента, яка включає в себе володіння ним специфічних якостей, необхідних йому для виконання ролі лідера у сфері публічного управління. Якості лідера як складові його лідерського потенціалу є практичною основою його успішної діяльності. Лідерство у публічній сфері припускає наявність у лідера необхідних знань і навичок, які формуються під час діяльності у ній. Тобто ми говоримо про те, що причиною їхньоо здобуття може бути успішна діяльність лідера у сфері публічного управління. Відповідно як педагогічну умову формування таких навичок у системі освіти можемо розглядати моделювання професійно-орієнтованих та практично спрямованих ситуацій із публічної сфери діяльності.

Отже, у межах освітнього процесу має бути створений комплекс педагогічних умов формування лідерської позиції майбутніх фахівців у сфері публічного управління та адміністрування. Наприклад, однією із умов може бути залучення студентів до різноманітних видів самостійної діяльності, теоретичне та практичне моделювання професійноорієнтованих ситуацій та інше.

У своїх попередніх публікаціях ми наголошували на тому, що “технологія процесу самовиховання студентів адміністративного менеджменту 3 метою розвитку у них лідерської позиції складається 3 таких елементів самовиховання: підготовчого, самопізнання, самооцінки, самоконтролю, самопрограмування на успіх, самовдосконалення, цілеспрямованої поведінки, формування компетентностей” [10, с. 63], а “результатом іiі здійснення виступає розвиток лідерської позиції студентів адміністративного менеджменту”, проте “використання технології про- 
цесу їхнього самовиховання сприяє їхній адаптації, індивідуалізації, інтеграції, що передбачає формування лідерської позиції, розвиток лідерських якостей через досягнення успіху в діяльності” [10, с. 64].

Не підлягає сумніву, що майбутній фахівець у сфері публічного управління та адміністрування, маючи на меті бути лідером, повинен володіти найкращими особистісними, професійними, комунікативними, психологічними якостями, постійно працювати над саморозвитком та самовдосконаленням, уміти ставити перед собою цілі і знати шляхи досягнення їх. Підготовка до професійної діяльності зумовлює у майбутнього фахівця у сфері публічного управління та адміністрування уміння діяти в інтересах людини, громади, держави, мати потребу у професіоналізації, розвитку комунікативної взаємодії під час реалізації функціональних обов'язків та безперервної самоосвіти [1, с. 14]. Тому сутність лідерської позиції майбутнього фахівця у сфері публічного управління та адміністрування ми розглядаємо як синергію його особистісних, професійних, громадянсь-

\section{Список літератури:}

1. Бєлова Л. О. Необхідність формування нової парадигми підготовки державно управлінських кадрів в Україні / Л. О. Бєлова // Публічне управління: стратегія реформ 2020: зб. тез. XV Міжнар.наук.конгресу, 23 квітня 2015 р. Х.: Вид-во ХарРІНАДУ "Магістр". - 2015. - С. 400

2. Власова Н. Ф. Сутність поняття “громадянська позиція" та шляхи іiі формування / Н. Ф. Власова // Педагогіка формування творчої особистості у вищій і загальноосвітній школах. -2016. - Вип 5 (104). - C. 110-117

3. Головешко Б. Р. Педагогічні умови формування лідерських якостей у майбутніх фахівців 3 адміністративного менеджменту у вищих навчальних закладах / Б. Р. Головешко // [Текст] : Автореф. дис. канд. пед. наук : 13.00.04 Вінниц. держ. пед. ун-т ім. Михайла Коцюбинського. - Вінниця. - 2017

4. Грищенко I. М. Лідерство як феномен управління групою / I. М. Грищенко // Інвестиції: практика та досвід.-№ 5.-С.116-119

5. Костиря I. В. Формування лідерської ких якостей, дій і вчинків, спрямованих на реалізацію його основної місії - готовності забезпечити конструктивну взаємодію публічної влади, освіти, науки, бізнесу i громадського суспільства.

Висновки 3 даного дослідження та перспективи подальших розвідок у даному напрямку. За результатами проведеного нами дослідження, сутність лідерської позиції майбутніх фахівців у сфері публічного управління та адміністрування визначаємо як синергію їхніх особистісних, професійних, громадянських якостей, дій і вчинків, спрямованих на реалізацію основної місії - готовності забезпечити конструктивну взаємодію публічної влади, освіти, науки, бізнесу і громадського суспільства; доведено, що усебічний розвиток їхньої особистості зможе забезпечити якісна професійна освіта, спрямована на формування їхньої лідерської позиції.

Перспективними напрямами подальшого дослідження є аналіз європейського досвіду формування лідерської позиції майбутніх фахівців у сфері публічного управління та адміністрування.

позиції майбутніх інженерів у вищих технічних навчальних закладах [електронний ресурс] / I. В. Костиря // Автореф. дис. канд. пед. наук : спец. 13.00.07 Вінницький держ. пед. університет ім. М. Коцюбинського. Вінниця. - 2018. - С. 20

6. Кричевский Р. Л. Психология лидерства: учебное пособие / Р. Л. Кричевский. М. : Статут. - 2007. - С. 542

7. Кудряшова Е. В. Лидер и лидерство: исследования лидерства в современной западной общественно-политической мысли / Е. В. Кудряшова. - Архангельск : Изд-во Поморского междунар. пед. ун-та. - 1996. -С. 256

8. Романовський О. Г. Лідерські якості в професійній діяльності / О. Г. Романовський, С. М. Резнік, Т. В.Гура, Ю. І. Панфілов, Б. Р. Головешко, В. В. Бондаренко. - Харків: НТУ "ХПІ". -2017. - С. 143

9. Романовський О. Г.Психологія управ- лінської діяльності лідера / О. Г. Романовський, О. С. Пономарьов, Т. В.Гура, А. Є.Книш, В. В. Бондаренко // Навчальний посібник. -Харків. - 2017. - С. 100

10. Резнік С. М. До питання формування лідерської позиції студентів адміністра- 
тивного менеджменту / С. М. Резнік, К. Ю. Підгорний // Лідери ХХІ століття. Формування особистості харизматичного лідера на основі гуманітарних технологій для управління соціальними системами: Матеріали IV міжнародної науково-практичної конференції 29-30 вересня 2020 року / За заг. ред. О. Г. Романовського. - Х.: НТУ "ХПІ". 2020. - С. 226

11. Романовский А. Г. Педагогика лідерства: Монографія / А. Г. Романовский В. Е. Михайличенко, Л. Н. Грень - Х.: НТУ "ХПИ". - 2018. - С. 500

12. Словник української мови: в 11 тт. / АН УРСР Інститут мовознавства; за ред. І. К. Білодіда. - К.: Наукова думка.-1970-1980

13. Сторожев В. Професійні компетенції лідерства в державному управлінні / Сторожев В. // Теорія та практика державного управління. - 2017. - № 3 (58). - С. 162-169

14. Стратегія сталого розвитку України до 2030 року [електронний ресурс]. - Режим доступу:https://igu.org.ua/sites/default/files/83.pdf

15. Романовський О. Г. Формування лідерської позиції майбутніх інженерів у закладах вищої технічної освіти / О. Г. Романовський, Т. В. Гура, С. М. Резнік, Ю. І. Панфілов, А. І. Черкашин, І. В. Костиря, В. В. Бондаренко. - Харків: НТУ “ХПІ". 2018. - С. 195

16. Хмизова О. В. Формування лідерської позиції у молодших школярів у позаурочній діяльності / О. В. Хмизова // Автореф. дис.. канд. пед. наук.13.00.07 - теорія і методика виховання. - К. -2010

17. Стогділл Р. М. Особисті фактори, пов'язані 3 лідерством: Огляд літератури / Р. М. Стогділл // Журнал психології. - 1948. Вип. 25

\section{References:}

1. Bielova, L. O. (2015), "The need to form a new paradigm for training public administration in Ukraine", Publichne upravlinnia: stratehiia reform 2020: zb. tez. KhV Mizhnar.nauk.konhresu, 23 kvitnia 2015, Kh.: vyd-vo KharRINADU "Mahistr", p. 400

2. Vlasova, N. F. (2016), "The essence of the concept of "civic position" and ways of its formation", Pedagogy of formation of creativity of the person in higher and comprehensive school, vip. 5 (104), pp. 110-117

3. Holoveshko, B. R. (2017), "Pedagogical conditions for the formation of leadership qualities in future specialists in administrative management in higher education", [Tekst] : avtoref. dys kand. ped. nauk : 13.00.04 Vinnytsia. state ped. Univ. Mykhailo Kotsyubynsky, Vinnytsia

4. Hryshchenko, I. M. "Leadership as a phenomenon of group management", Investments: practice and experience, no. 5. pp. 116-119

5. Kostyria, I. V. (20180, "Formation of a leading position of future engineers in higher technical educational institutions", avtoref. dys. ... kand. ped. nauk : spets. 13.00.07 Vinnytskyi derzh. ped. un-t im. M. Kotsiubynskoho. Vinnytsia, p. 20

6. Krychevskyi, R. L. (2007), "Psychology of leadership", uchebnoe posobye, M. : Statut, p. 542

7. Kudriashova, E. V. (1996), "Leader and Leadership: Studies of Leadership in Contemporary Western Socio-Political Thought", Arkhangelsk: Pomeranian International Publishing House. ped. un-ta., p. 256

8. Romanovskyi, O. H., Reznik, S. M., Hura, T. V., Panfilov, Yu. I, Holoveshko, B. R., Bondarenko, V. V. (2017), "Leadership qualities in professional activities", Kharkiv: NTU "KhPI", p. 143

9. Romanovskyi, O. H., Ponomarov, O. S., Hura, T. V., Knysh, A. Ie., Bondarenko, V. V. (2017), "Psychology of managerial management", Tutorial, Kharkiv, p.100

10. Reznik, S. M., Pidhornyi, K. Yu. (2020), "On the issue of forming the leadership position of students of administrative management", Leaders of the XXI century. Formation of features of the charismatic leader on the basis of humanitarian technologies for management of social systems: Proceedings of the IV international scientific-practical conference on September 29-30, 2020 Za zah. red. Romanovsky O. Kh., Kh.: NTU “KhPI”, p. 226

11. Romanovskyi, A. H., Hren, L. N., Mykhailychenko, V. E. (2018), "Leadership pedagogy”, Monohrafiia, Kh.: NTU "KhPY”, p. 500

12. "Dictionary of the Ukrainian language", USSR. Institute of Linguistics; for red. I. K. Bilodida, K :: Scientific opinion, v. 11 tt., 1970-1980 
13. Storozhev, V. (2017), "Professional competencies of leadership in public administration", Theory and practice of public administration, no. 3 (58), pp. 162-169

14. "Strategy of sustainable development of Ukraine until 2030", available at: https://igu.org.ua/sites/default/files/83.pdf

15. Romanovskyi, O. H., Hura, T. V., Reznik, S. M., Panfilov, Yu. I, Cherkashyn, A. I., Kostyria, I. V., Bondarenko, V. V. (2018), "Formation of a leading position of future engineers in institutions of higher technical education”, Kharkiv: NTU “KhPI”, p. 195

16. Khmyzova, O.V. (2010), "Formation of leadership position in junior high school students in extracurricular activities", avtoref. dys.. kand. ped. nauk.13.00.07 - theory and methods of education, $\mathrm{K}$.

17. Stogdill, R. M. (1948), "Personal Factors associated with Leadership: A Survey of Literature", Journal of Psychology, vol. 25 